\title{
MASALAH PSIKOSOSIAL PADA PENYANDANG TALASEMIA USIA SEKOLAH DI POLIKLINIK TALASEMIA RSUD SUMEDANG
}

\author{
Julvia Nurvitasari $^{1}$, Ai Mardhiyah ${ }^{2}$, Ikeu Nurhidayah ${ }^{3}$ \\ Fakultas Keperawatan Universitas Padjadjaran \\ ${ }^{1}$ Mahasiswa Fakultas Keperawatan Universitas Padjadjaran \\ ${ }^{2,3}$ Staf Pengajar Fakultas Keperawatan Universitas Padjadjaran \\ E-mail: ai.mardhiyah@unpad.ac.id
}

\begin{abstract}
ABSTRAK
Masalah psikososial pada penyandang talasemia usia sekolah dapat berdampak negatif pada perkembangan, pendidikan, gangguan perilaku, depresi, dan isolasi sosial. Penelitian ini bertujuan untuk mengidentifikasi masalah psikososial pada penyandang talasemia usia sekolah di Poliklinik Talasemia Rumah Sakit Umum Daerah Sumedang. Penelitian ini merupakan penelitian deskriptif kuantitatif, populasinya adalah orang tua penyandang talasemia usia sekolah di Poliklinik talasemia RSUD Sumedang. Sejumlah 52 responden berpartisipasi dalam penelitian ini dan diambil dengan total sampling. Pengukuran masalah psikososial menggunakan kuesioner Pediatric Symptoms Checklist-17 dari Jellinek. Data dianalisis menggunakan analisis deskriptif yaitu persentase. Hasil penelitian didapatkan bahwa kurang dari setengah (31\%) anak mengalami masalah psikososial. Berdasarkan dimensi, kurang dari setengah anak mengalami masalah internal (40,3\%), serta sebagian kecil anak mengalami masalah eksternal (7,7\%) dan perhatian $11,5 \%$. Simpulan penelitian ini yaitu anak talasemia memiliki psikososial yang baik, namun terdapat kecenderungan anak rentan mengalami masalah psikososial. Upaya yang dapat dilakukan perawat adalah preventif melalui deteksi masalah psikososial sejak dini dan berkesinambungan untuk mengidentifikasi adanya masalah psikososial, sehingga dapat diantisipasi sejak dini.
\end{abstract}

Kata Kunci : : masalah psikososial, talasemia, usia sekolah

\begin{abstract}
Psychosocial problems in school age children with thalassemia may cause a negative impact on development, education, behavioral disorders, depression, and social isolation. This study aims to identify the psychosocial problems in school age children with thalassemia at Thalassemia Policlinic of Sumedang Regional General Hospital. This study is a quantitative descriptive study. The population of this study are focused to parents who have school age children with thalassemia at Thalassemia Policlinic of Sumedang Regional General Hospital. Total number of respondents are 52 who participated in this study which is total sampling. To measure the psychosocial problems this study used Pediatric Symptoms Checklist-17 questionnaire from Jellinek. All data were analyzed using descriptive analysis in percentage. The results showed that less than half (31\%) children had psychosocial problems. Based on the dimensions, less than half of children had internal problems (40.3\%), and a minority of children had external problems (7.7\%) and attention (11,5\%). Conclusions of this study that children with thalassemia have a good psychosocial, but they tend to be at risk of psychosocial problem. Nursing efforts are needed in preventive through early detection of psychosocial and continuous to identify the existence of psychosocial problem, so it can be anticipated.
\end{abstract}

Keyword : psychosocial problems, thalassemia, school age children

\section{PENDAHULUAN}

Talasemia merupakan penyakit kelainan darah kongenital resesif karena kurangnya atau menurunnya produksi hemoglobin (Rejeki, Nurhayati, Supriyanto, \& Kartikasari, 2012). World Health Organization menyatakan bahwa penduduk dunia dengan gen talasemia sebesar 7\% dan $40 \%$ diantaranya terjadi di Asia (WHO, 2012). Tahun 2014 Yayasan Talasemia Indonesia Perhimpunan Orang Tua Penderita Talasemia Indonesia melaporkan 6.647 penduduk Indonesia tercatat menyandang talasemia dan meningkat pada tahun 2017 menjadi 9.131 
orang. 42,8 \% penyandang diantaranya berasal dari Jawa Barat (YTI 2010 (dalam Wartini, 2013)). Hasil tersebut tidak menutup kemungkinan terjadi di RSUD Sumedang yang merupakan salah satu rumah sakit pemerintahan di Jawa Barat dengan fasilitas layanan talasemia.

Penanganan talasemia terdiri atas transfusi darah, terapi kelasi besi, dan terapi suplemen asam folat (Caocci et al., 2012). Menurut Surilena (2014) semakin bertambahnya usia penyandang talasemia, dampak dari penyakit maupun penanganannya akan bertambah baik fisik maupun psikologis. Dampak fisik yang dialami berupa perubahan warna kulit menjadi kehitaman, pucat, rambut menipis, dan perut membesar. Sedangkan dampak psikologis berupa perasaan bosan, jenuh, dan putus asa. Dampak fisik yang dialami juga mengakibatkan dampak psikologis berupa perasaan berbeda dengan teman sebayanya, perasaan sensitif, prasaan cemas dan rasa takut pada lingkungannya. Keadaan tersebut membuat kehilangan rasa percaya diri dalam berinteraksi sosial, hingga dapat memengaruhi psikososial penyandang talasemia (Surilena, 2014).

Psikososial merupakan keterkaitan prinsipprinsip dari perkembangan secara psikologi dan sosial (Erikson, 1989). Sarafino dan Smith (2011) menggambarkan bahwa psikologis dan sosial individu dipengaruhi kondisi sakit seseorang. Psikososial penyandang talasemia bervariasi, tergantung mereka memandang rasa sakit yang diderita dan penanganan yang dijalaninya (Rizkia \& Yusuf, 2017). Umumnya psikososial seseorang ditunjukkan atas psikososial yang tidak mengalami masalah dan psikososial yang mengalami masalah. Tidak adanya masalah ditunjukkan melalui dukungan, kekuatan, dan keberanian untuk bertindak positif seperti perasaan menerima dan siap menjalankan tugas. Sebaliknya begitupun pada penyandang talasemia yang mengalami masalah psikososial.

Masalah psikososial pada anak dengan penyakit kronis non-neurologis rentan dua kali lebih besar dibandingkan pada anak sehat (Glazebrook., Hollis, Heussler, Goodman, \& Coates, 2003). Menurut Achenbach dan Conaughy (1997) masalah psikososial merupakan perubahan psikologis dan sosial yang berpengaruh terhadap hubungan interpersonal yang tidak stabil, kemampuan bekerja yang buruk, dan menyebabkan kekerasan interpersonal. Masalah psikososial pada penyandang talasemia akan berpengaruh terhadap penurunan kualitas kesehatan, sehingga seseorang yang berada dalam kondisi tersebut akan merasakan situasi yang menekan.

Anak usia sekolah menurut Wong (2008) adalah anak yang berusia 6-12 tahun, sama halnya dengan data pasien yang ada pada instalasi rawat jalan talasemia RSUD Sumedang yang di dominasi oleh anak usia 6-11 tahun. Tahapan perkembangan psikososial pada usia sekolah menurut Erikson (1989) yaitu berupa kemampuan akademik dan sosial anak yang sudah mulai berkembang untuk berinteraksi di luar keluarga. Anak usia sekolah yang mengalami masalah psikososial akan mengalami kesulitan dalam menyesuaikan diri pada aktivitas sehari-hari seperti bersosialisasi, dan sulit mengembangkan kemampuan akademik.

Hadirnya penyakit talasemia memberi beban psikososial yang luar biasa bagi penyandang maupun orang tuanya (Mediani, Nurhidayah, Mardhiyah, \& Panigoro, 2017). Penelitian Mulyani dan Fahrudin (2011) diketahui bahwa psikososial penyandang talasemia di kota Bandung berada dalam kategori masalah sedang dengan reaksi yang ditimbulkan bervariasi. Psikososial yang buruk pada penyandang talasemia ditunjukan dengan reaksi malas, hilang nafsu makan, berat 
badan menurun, sulit konsentrasi, sulit tidur, gangguan mood, dan tidak memiliki harapan hidup (Mulyani \& Fahrudin, 2011).

Masalah pada anak dinilai melalui tiga dimensi yaitu internal, eksternal, serta perhatian (Achenbach \& Conaughy 1997; Gardner, Murphy, \& Childs, 1999). Masalah internal merupakan masalah yang ditunjukkan dari perasaan dalam diri, gejala yang ditunjukkan berupa cemas, perasaan sedih, depresi, dan penarikan sosial (Cakaloz et al., 2009). Selanjutnya adalah masalah eksternal, yaitu masalah yang terlibat saat anak berinteraksi dengan orang lain, gejala yang ditunjukkan berupa kenakalan, mengganggu, dan sifat agresif (Cakaloz et al., 2009). Dan masalah perhatian yang dapat ditemukan ketika anak terlihat sulit untuk menerima nasehat, sulit konsentrasi, sering melamun, serta perhatian yang mudah dialihkan.

Masalah psikososial yang terjadi pada penyandang talasemia dipengaruhi oleh faktor durasi penyakit dan lama pengobatan, status sosioekonomi, serta tingkat pendidikan orang tua, usia anak, dan jenis kelamin (Adriani, Rusmil, \& Hilmanto 2012). Selain itu, dinamika keluarga, nilai budaya dan peran masyarakat turut memengaruhi masalah psikososial pada penyandang talasemia (Erikson, (1989). Frekuensi absen dari sekolah, hubungan teman sebaya terganggu, status ekonomi, perlindungan berlebih, dan tuntutan interpersonal orang tua terhadap anak akan mengganggu fungsi sekolah, sehingga dapat memengaruhi masalah psikososial anak (Saini, Chandra, Goswami, Singh, \& Dutta, 2007).

RSUD Sumedang merupakan salah satu Rumah Sakit dengan fasilitas layanan poliklinik talasemia yang ada di Jawa Barat. Tahun 2013 hingga November 2017 jumlah pengunjung poliklinik talasemia RSUD Sumedang meningkat setiap tahunnya. Tahun 2013 terdapat 116 penyandang talasemia dan pada November 2017 jumlah penyandang menjadi 140 penyandang. Satu tahun terakhir tercatat, kebanyakkan pengunjung poliklinik talasemia RSUD Sumedang adalah anak usia sekolah yaitu usia 6-11 tahun sebanyak 52 penyandang. Selain rawat jalan terdapat penyandang talasemia yang melakukan rawat inap di RSUD Sumedang, meski dengan jumlah penyandang yang fluktuatif.

Hasil wawancara terhadap 9 orang tua penyandang tasaemia usia sekolah di poliklinik talasemia RSUD Sumedang diperoleh gambaran bahwa 7 anak mudah marah, 3 anak mudah sensitif, 2 anak mudah malu, 2 anak suka melamun, dan 2 anak lainnya dapat berinteraksi dengan teman-teman dilingkungannya. Peneliti juga melakukan observasi dan diperoleh gambaran bahwa beberapa anak tampak sedih dan melamun saat tidak didampingi orang tua. Hasil gambaran yang diperoleh peneliti melalui wawancara dan observasi didapatkan bahwa gambaran tersebut menunjukkan adanya masalah psikososial (Keliat et al., 2011). Sejauh ini, upaya yang diberikan orang tua penyandang talasemia berupa dukungan dalam menjalani penanganan. Hal tersebut terlihat ketika orang tua yang hadir mendampingi anaknya selama penanganan transfusi.

Melalui hasil wawancara juga diketahui bahwa penanganan talasemia di RSUD Sumedang hanya sebatas penanganan aspek fisik saja seperti transfusi darah dan pemberian obat-obatan. Penanganan secara psikologis oleh petugas kesehatan belum dirasakan oleh orang tua anak talasemia. Menurut Cakaloz et at (2009) penting memperhatikan biologis, sosial, dan psikologis anak secara menyeluruh, terlebih pada anak talasemia yang memiliki risiko peningkatan psikopatologi. Oleh karena itu penting memberi perhatian tidak hanya terbatas pada aspek perubahan fisik namun juga psikologis seperti masalah psikososial. 
Masalah psikososial penting diketahui, karena menyebabkan penyandang talasemia usia sekolah sulit dalam menyesuaikan diri dengan aktivitas seharihari seperti bersosialisasi, belajar atau bersekolah, dan masalah perilaku (Ihwanah, 2017). Selain itu, timbulnya suatu penyakit pada proses maturasi fisik dan psikososial dapat mengganggu kualitas hidup seseorang (Loonen et al., 2001). Terganggunya kualitas hidup pada penyandang talasemia usia sekolah salah satunya ditandai dengan menurunnya fungsi sekolah. Berdasarkan hasil wawancara, beberapa orang tua mengungkapkan bahwa anaknya sering bolos sekolah, sudah merasa lelah dengan penyakitnya, dan sering bertanya soal kematian.

Banyaknya dampak yang ditimbulkan dari masalah psikososial, maka perlu dilakukan penanganan secara tepat. Salah satu yang dapat dilakukan perawat adalah dengan deteksi masalah psikososial. Deteksi dimaksudkan untuk mengetahui apakah anak memiliki indikasi masalah psikososial atau tidak. Setelah hasil deteksi didapatkan, nantinya perawat diharapkan dapat memberi intervensi sesuai dimensi yang memiliki indikasi masalah dan melakukan Health Teaching dimana perawat berdiskusi dengan orang tua, memberitahu tahap perkembangan anak sehingga orang tua sadar akan apa yang terjadi pada anak dan dapat mengantisipasi timbulnya masalah (Yanitawati, Mardhiyah, \& Widianti, 2017).

Terdapat beberapa penelitian mengenai masalah psikososial penyandang talasemia yang dipublikasikan. Penelitian yang ada hanya mengidentifikasi tingkat keparahan masalah psikososial dan tidak dikelompokkan pada kelompok usia tertentu. Sedangkan pada penelitian ini, peneliti akan mengidentifikasi masalah psikososial dalam tiga dimensi yaitu internal, eksternal, dan perhatian pada penyandang talasemia usia sekolah
(Achenbach \& Conaughy 1997; Gardner, Murphy, \& Childs, 1999). Sehingga apabila akan diberikan intervensi, dapat diberikan intervensi sesuai dimensi yang mengalami masalah. Penelitian di wilayah Jawa Barat masih terbatas hanya dilakukan di Bandung. Disamping itu, belum ditemukannya penelitian mengenai masalah psikososial di wilayah Sumedang dan sekitarnya membuat peneliti merasa perlu untuk melakukan penelitian ini. Sehingga, penting untuk mengidentifikasi bagaimana masalah psikososial penyandang talasemia usia sekolah di poliklinik talasemia RSUD Sumedang yang setiap tahunnya mengalami peningkatan jumlah penyandang talasemia

\section{METODE PENELITIAN}

Jens penelitian ini adalah deskriptif kuantitatif, yang bertujuan untuk melihat gambaran masalah psikososial pada penyandang talasemia usia sekolah di Poliklinik talasemia RSUD Sumedang. Sampel diambil menggunakan total sampling sejumlah 52 orang responden. Instrumen yang digunakan Pediatric Symptoms Checklist-17 untuk screening psikososial anak usia 4-16 tahun. Kuesioner ini diukur menggunakan skala likert dengan pilihan jawaban : $0=$ tidak pernah, 1 = kadang-kadang, 2 = sering.

Pengumpulan data dimulai dengan mengajukan permohonan etik penelitian Komite Etik Fakultas Kedokteran Universitas Padjadjaran dan izin penelitian di RSUD Sumedang. Teknik pengumpulan data dilakukan dengan menyebarkan kuesioner. Sebelum memberikan kuesioner peneliti melakukan informed consent, dan menjelaskan bahwa jawaban yang diberikan responden akan dijaga kerahasiannya. Data yang terkumpul selanjutnya diolah oleh peneliti. Data disajikan dalam bentuk distribusi frekuensi dan persentase. 


\section{HASIL PENELITIAN}

Penyajian data karakteristik demografi responden dalam penelitian ini berupa distribusi frekuensi.

Tabel 1 Distribusi Frekuensi Karakteristik Responden Penyandang Talasemia Usia Sekolah di Poliklinik Talasemia RSUD Sumedang $(n=52)$

\begin{tabular}{|c|c|c|}
\hline Karakteristik & $\begin{array}{l}\text { Frekuensi } \\
\text { (f) }\end{array}$ & $\begin{array}{l}\text { Presentase } \\
(\%)\end{array}$ \\
\hline \multicolumn{3}{|l|}{ Pendidikan } \\
\hline \multicolumn{3}{|l|}{ Terakhir } \\
\hline \multicolumn{3}{|l|}{ Orang Tua } \\
\hline SD & 19 & 36,5 \\
\hline SMP & 15 & 28,8 \\
\hline SMA & 14 & 26,9 \\
\hline Perguruan & 4 & 7,7 \\
\hline \multicolumn{3}{|l|}{ Tinggi } \\
\hline \multicolumn{3}{|l|}{ Penghasilan } \\
\hline \multicolumn{3}{|l|}{ Orang Tua } \\
\hline Kurang & 40 & 76,9 \\
\hline dari UMR & & \\
\hline \multicolumn{3}{|l|}{ Kota } \\
\hline \multicolumn{3}{|l|}{ Sumedang } \\
\hline \multicolumn{3}{|l|}{$(<$} \\
\hline \multicolumn{3}{|l|}{$2.670 .000)$} \\
\hline Lebih dari & 12 & 23,1 \\
\hline \multicolumn{3}{|l|}{ UMR Kota } \\
\hline \multicolumn{3}{|l|}{ Sumedang } \\
\hline \\
\hline \multicolumn{3}{|l|}{$\geq 2.670 .000$} \\
\hline \multicolumn{3}{|l|}{ ) } \\
\hline \multicolumn{3}{|l|}{ Suku } \\
\hline Sunda & 47 & 90,4 \\
\hline Jawa & 4 & 7,7 \\
\hline Padang & 1 & 1,9 \\
\hline \multicolumn{3}{|l|}{ Usia Anak } \\
\hline 6-7 Tahun & 11 & 21,1 \\
\hline 8-9 Tahun & 14 & 27,0 \\
\hline $10-12$ & 27 & 51,9 \\
\hline \multicolumn{3}{|l|}{ Tahun } \\
\hline \multicolumn{3}{|l|}{ Jenis Kelamin } \\
\hline \multicolumn{3}{|l|}{ Anak } \\
\hline Laki-laki & 27 & 51,9 \\
\hline Perempuan & 25 & 48,1 \\
\hline \multicolumn{3}{|l|}{ Kunjungan } \\
\hline \multicolumn{3}{|l|}{ Transfusi } \\
\hline \multicolumn{3}{|l|}{ bulan) } \\
\hline 1 Kali & 12 & 23,1 \\
\hline 2 Kali & 27 & 51,9 \\
\hline 3 Kali & 5 & 9,6 \\
\hline 4 Kali & 7 & 13,5 \\
\hline$>4$ Kali & 1 & 1,9 \\
\hline \multicolumn{3}{|l|}{ Urutan anak } \\
\hline Anak Ke 1 & 26 & 50 \\
\hline Anak Ke 2 & 19 & 36,5 \\
\hline
\end{tabular}

\begin{tabular}{cll}
\hline Anak Ke 3 & 5 & 9,6 \\
Anak Ke 4 & 1 & 1,9 \\
Anak Ke 5 & 1 & 1,9 \\
Jumlah & & \\
Saudara & & \\
1 Orang & 14 & 26,9 \\
2 Orang & 23 & 44,2 \\
3 Orang & 12 & 23,1 \\
4 Orang & 2 & 3,8 \\
5 Orang & 1 & 1,9 \\
Lama & & \\
Menderita & 51 & $98,0 \%$ \\
>5 Tahun & 1 & $2,0 \%$ \\
<5 Tahun & & \\
\hline
\end{tabular}

Hasil menampilkan dua kategori yaitu mengalami masalah dan tidak mengalami masalah yang tersaji dengan hasil sebagai berikut

Tabel 2 Masalah Psikososial Penyandang Talasemia Usia Sekoalah di Poliklinik Talasemia RSUD Sumedang $(n=52)$

\begin{tabular}{lll}
$\begin{array}{l}\text { Kategori } \\
\text { Masalah } \\
\text { psikososial }\end{array}$ & $\begin{array}{l}\text { Frekuensi } \\
(\mathbf{f})\end{array}$ & $\begin{array}{l}\text { Presentase } \\
(\boldsymbol{\%})\end{array}$ \\
\hline $\begin{array}{l}\text { Mengalami } \\
\text { masalah }\end{array}$ & 16 & 31 \\
$\begin{array}{l}\text { Tidak mengalami } \\
\text { masalah }\end{array}$ & 36 & 69 \\
\hline
\end{tabular}

Berdasarkan Tabel 2 penyandang talasemia usia sekolah di poliklinik talasemia RSUD Sumedang yang mengalami masalah adalah kurang dari setengah anak (31\%).

Tabel 3 Dimensi Masalah Psikososial Penyandang Talasemia Usia Sekolah di Poliklinik Talasemia RSUD Sumedang $(n=52)$

\begin{tabular}{lll}
\hline Dimensi & $\begin{array}{l}\text { Frekuensi } \\
\text { (f) }\end{array}$ & $\begin{array}{l}\text { Presentase } \\
(\%)\end{array}$ \\
\hline $\begin{array}{l}\text { Masalah Internal } \\
\quad \text { Mengalami }\end{array}$ & 21 & 40,3 \\
Masalah & 31 & 59,7 \\
$\quad$ Tidak & & \\
mengalami masalah & & \\
$\begin{array}{l}\text { Masalah Eksternal } \\
\quad \text { Mengalami }\end{array}$ & 4 & 7,7 \\
$\begin{array}{l}\text { Masalah } \\
\quad \text { Tidak }\end{array}$ & 48 & 92,3 \\
$\begin{array}{l}\text { mengalami masalah } \\
\text { Masalah Perhatian }\end{array}$ & & \\
$\quad \begin{array}{l}\text { Mengalami } \\
\text { Masalah }\end{array}$ & 6 & \\
$\quad \begin{array}{l}\text { Tidak } \\
\text { mengalami }\end{array}$ & 46 & 11,5 \\
$\quad$ masalah & & 88,5 \\
\hline
\end{tabular}


Tabel 3 menunjukkan hasil sebanyak 21 anak mengalami masalah internal, 4 anak mengalami masalah eksternal, dan 6 anak mengalami masalah perhatian.

\section{PEMBAHASAN}

Hasil penelitian menunjukkan kurang dari setengah anak responden (31\%) mengalami masalah psikososial. Hasil penelitian ini menunjukkan angka yang lebih rendah dibandingkan dengan penelitian yang dilakukan Mulyani dan Fahrudin (2011) di salah satu kota di Jawa Barat. Perbedaan hasil yang diperoleh mungkin dikarenakan usia anak yang diteliti berbeda, dimana pada penelitian sebelumnya dilakukan kepada usia remaja. Hal tersebut terjadi mungkin karena pada anak usia sekolah peran dan tanggung yang dimiliki belum sebesar anak usia remaja. Menurut Achenbach dan Conaughy (1997) masalah psikososial merupakan perubahan psikologis dan sosial yang berpengaruh terhadap kehidupan lingkungan seperti hubungan interpersonal tidak stabil, kemampuan bekerja buruk, dan menyebabkan kekerasan interpersonal.

Tabel 2 menunjukkan hasil masalah psikososial pada penyandang talasemia usia sekolah dalam tiga dimensi yaitu internal, eksternal, dan perhatian. Sejalan dengan Achenbach dan Conaughy (1997); Gardner, Murphy, dan Childs, (1999) yang menilai masalah anak dilihat dalam tiga dimensi yaitu internal, eksternal, dan perhatian. Hasil penelitian diketahui kebanyakan anak atau kurang dari setengah anak responden mengalami masalah internal (40,3\%), sebagian kecil anak mengalami masalah eksternal $(7,7 \%)$, dan sebagia kecil mengalami masalah perhatian $(11,5 \%)$.

Masalah internal merupakan masalah yang mengarah kepada diri sendiri yang ditunjukkan melalui perasaan dalam diri seseorang. Masalah internal yang ditunjukkan berdampak terhadap timbulnya perasaan bersalah, perasaan penolakan, serta kelesuan sistem diri rendah yang sering terabaikan. Riyana dan Riza (2017) dalam penelitiannya, masalah yang dialami kebanyakan anak adalah masalah internal. Hal tersebut sesuai dengan hasil penelitian ini, kebanyakan anak mengalami masalah internal yaitu kurang dari setengah penyandang talasemia $(40,3 \%)$ dari total 52 anak responden. Menurut Stewart (2005) faktor yang dapat menyebabkan masalah internal diantaranya penyakit yang diderita. Faktor penyakit yang diderita terhadap timbulnya masalah psikososial internal, memiliki keterkaitan dengan rutinitas rawat jalan dan lama sakit.

Hasil dimensi yang mengalami masalah internal dalam penelitian ini menunjukan lebih dari setengah anak memiliki kunjungan 2 kali dalam 1 bulan $(57,1 \%)$. Keadaan tersebut mungkin akan memengaruhi psikologis dan sosial anak, dimana frekuensi absen anak dari sekolah dapat membuat anak menjadi tertekan karena tertinggal pelajaran dan terganggunya hubungan sosial anak dengan teman sekolahnya. Sehingga keadaan tersebut dapat memengaruhi terjadinya masalah psikososial anak. Sebagian besar anak telah menderita talasemia $\geq 5$ tahun $(98,0 \%)$. Hasil tersebut sejalan dengan penelitian Rahmawati et al (2016) terhadap penderita penyakit kronis, dimana banyak anak yang menderita penyakit kronis $\geq 5$ tahun dan ditemukan mengalami masalah psikososial. Hal tersebut mungkin membuat anak merasa lelah dengan segala tututan rutinitas penanganan yang harus dijalanai sehingga memengaruhi psikososial anak.

Masalah eksternal merupakan masalah yang timbul dan mengarah kepada orang lain, dan melibatkan lingkungan. Masalah eksternal tergambar ketika anak berinteraksi dengan orang lain, dengan sikap agresif yang ditunjukkan untuk dirinya sendiri maupun orang lain 
(Achenbach \& Conaughy 1997; Gardner et al., 1999). Hasil penelitan menunjukkan sebagian kecil anak penyandang talasemia mengalami masalah eksternal $(7,7 \%)$ dari total 52 anak responden.

Hal tersebut mungkin karena anak telah mampu menerima dan beradaptasi dengan penyakit yang dideritanya. Menurut Supratiknya (1995) salah satu faktor masalah psikososial dipengaruhi lingkungan, ditunjukkan melalui adanya diskriminasi penggolongan suku. Hasil penelitian diketahui sebagian besar responden memiliki suku sunda $(90,4 \%)$. Hal tersebut mungkin mempermudah anak menyesuaikan diri dengan lingkungannya, untuk dapat berinteraksi sosial dengan orang lain. Pengamatan selama penelitian, poliklinik talasemia RSUD Sumedang telah menciptakan lingkungan yang baik, terlihat ketika anak mampu berinteraksi dengan baik selama berada di Poliklinik talasemia. Peran orang-orang di Poliklinik yang menunjukkan sikap ramah dan menerima, turut mendukung anak dalam mewujudkan hubungan interaksi yang baik.

Masalah perhatian merupakan masalah yang banyak tergambarkan melalui perubahan yang terjadi pada anak. Hadirnya masalah perhatian pada anak biasanya ditandai oleh ketidakmampuan mempertahankan perhatian, sering melamun, dan sulit mengatur tingkat aktivitas yang berlebih (Achenbach \& Conaughy 1997; Gardner et al., 1999). Hasil penelitian menunjukkan $11,5 \%$ dari total 52 anak responden mengalami masalah perhatian. Artinya, hanya sebagian kecil anak yang mengalami masalah perhatian.

Hasil tersebut mungkin dipengaruhi oleh perhatian yang diberikan orang tua dan attachment yang baik antara orang tua dengan anak. Menurut Halimah, Allenidekania, dan Waluyanti (2016) pendampingan orang tua sangatlah penting pada anak talasemia. Pengamatan peneliti selama penanganan transfusi, orang tua selalu memberikan perhatian kepada anaknya tergambar ketika orang tua selalu mendampingi anak dan menanyakan terkait keluhan yang dirasakan anaknya selama proses transfusi. Sedangkan untuk kedekatan yang dimiliki antara orang tua dan anak menunjukkan hubungan yang baik. Hubungan tersebut terlihat ketika orang tua yang setia mendampingi anak selama penanganan transfusi rutin dan orang tua mengajak anaknya bercerita untuk mengalihkan rasa bosan yang dialami anak. Hal tersebut mungkin merupakan salah satu wujud upaya orang tua memberi dukungan kepada anak dalam menghadapi penyakit yang dideritanya.

Perlu dilakukan penelitian lebih lanjut untuk mengetahui faktor-faktor yang memengaruhi munculnya masalah psikososial pada penyandang talasemia. Terdapat beberapa kemungkinan faktor lainnya yang memengaruhi timbulnya masalah psikososial seperti faktor durasi penyakit dan lama pengobatan, pendidikan terakhir orang tua, jenis kelamin dan usia anak, status sosio ekonomi, dan sosiokultural (Supratiknya, 1995; Markum, 2015; Notoatmodjo \& Soekidjo, 2003). Masalah psikososial yang tidak ditindak lanjut dapat berdampak pada berbagai kesulitan bagi anak dalam menyesuaikan diri dengan aktivitas sehari-hari seperti bersosialisasi, belajar, dan masalah perilaku (Ihwanah, 2017). Penelitian Caocci et al., (2012) menyebutkan bahwa beban psikososial dapat menimbulkan kecemasan, isolasi sosial hingga depresi.

Perubahan fungsi-fungsi akibat masalah psikososial anak talasemia merupakan bagian dari kualitas hidup anak. Perubahan tersebut merupakan masalah keperawatan yang perlu mendapat penanganan secara tepat, oleh karena itu diperlukan peran perawat yang dapat menangani masalah psikososial anak melalui asuhan keperawatan. Upaya yang dapat dilakukan 
oleh perawat dalam mengatasi masalah psikososial pada penyandang talasemia adalah dengan melakukan upaya preventif melalui deteksi dini. Perawat melakukan deteksi masalah psikososial dengan melakukan pendekatan komunikasi interpersonal melalui pendekatan kultural, sosiologis, dan psikologis (Heri Zan Pieter, 2017). Setelah dilakukan deteksi, dan telah didapatkan hasil, selanjutnya perawat dapat memberikan intervensi sesuai dengan dimensi masalah psikososial yang dialami anak talasmia yang meliputi masalah internal, eksternal, dan perhatian.

Pada penelitian ini masalah psikososial dilihat melalui dimensi masalah psikososial secara keseluruhan dan juga dibahas mengenai karakteristik demografi responden serta karakteristik anak responden. Namun pada penelitian ini tidak dibahas secara spesifik terkait faktorfaktor yang memengaruhi masalah psikososial pada penyandang talasemia. Penting untuk diketahui faktor-faktor yang memengaruhi masalah psikososial, sehingga diharapkan hasil penelitian ini dapat dijadikan data awal untuk selanjutnya mengidentifikasi faktor-faktor yang memengaruhi masalah psikososial anak.

\section{KESIMPULAN}

Masalah psikososial pada penyandang talasemia usia sekolah di Poliklinik talasemia RSUD Sumedang menunjukkn bahwa kurang dari setengah anak responden mengalami masalah psikososial. Berdasarkan dimensi, kebanyakan anak atau kurang dari setengah anak responden mengalami masalah internal, dan sebagian kecil mengalami masalah eksternal serta perhatian.

\section{DAFTAR PUSTAKA}

Achenbach, \& Conaughy, M. (1997). Empirically-based Assessment of Child and Adolescent Psychopatology (2nd end). Sage, Thousand Oaks, CA. Adriani, N., Rusmil, K., \& Hilmanto, D. (2012). Faktor Risiko Masalah Psikososial. J Indon Med Assoc, 62(2), 56-59.

Caocci, G., Efficace, F., Ciotti, F., Roncarolo, M. G., Vacca, A., Piras, E., .. La Nasa, G. (2012). Health related quality of life in Middle Eastern children with betathalassemia. BMC Blood Disorders, 12(1), 6. https://doi.org/10.1186/1471-2326$\underline{12-6}$

Erikson. (1989). Identitas dan Siklus Hidup Manusia, terj. Agus Cremes. Jakarta: Gramedia.

Gardner, Murphy, \& Childs. (1999). a brief including psychosocial problem sbubscales. Ambul Child Health, 5, 225-236.

Glazebrook., C., Hollis, C., Heussler, H., Goodman, R., \& Coates, L. (2003). Detecting Emotional and Behavioural Problems In Paediatric Clinics, 29(2), 141-149.

https://doi.org/10.1046/j.13652214.2003.00324.x

Halimah, Allenidekania, \& Waluyanti, F. T. (2016). RESIKO REMAJA THALASEMIA TERHADAP PERUBAHAN PERILAKU Halimah. Ners Jurnal Keperawatan, 12(1), 2327.

Heri Zan Pieter, S. P. dkk. (2017). Dasardasar Komunikasi bagi Perawat (1st ed.). Jakarta: K E N C A N A.

Ihwanah, N. A. (2017). Hubungan Pola Asuh dengan Masalah Psikososial pada Anak di SD Negeri Pajang 1 Surakarta.

Keliat, Helena, \& Farida. (2011). Manajemen Keperawatan Psikososial \& Kader Kesehatan Jiwa; CMHN (Intermediate Course) (Cetakan I). Jakarta: EGC.

Mediani, H. S., Nurhidayah, I., Mardhiyah, A., \& Panigoro, R. (2017). International Journal of Nursing \& Care Indonesian Mothers $\hat{a} €^{\mathrm{TM}}$ Needs 
and Concerns about Having a Thalassemic Child and Its Treatment : An Exploratory Qualitative Study. Int J Nur Care, 1(2).

Rahmawati, L., Soedjatmiko, S., Gunardi, H., Sekartini, R., Batubara, J. R., \& Pulungan, A. B. (2016). Gangguan Perilaku Pasien Diabetes Melitus tipe1 di Poliklinik Endokrinologi Anak Rumah Sakit Cipto Mangunkusumo. Sari Pediatri, 9(4), 264. https://doi.org/10.14238/sp9.4.2007.2 64-9

Rejeki, D. S. S., Nurhayati, N., Supriyanto, \& Kartikasari, E. (2012). Studi Epidemiologi Deskriptif Talasemia. Kesmas: Jurnal Kesehatan Masyarakat, 7(3), 139-144. https://doi.org/10.21109/kesmas.v7i3. 61

Riyana, M., \& Riza, M. (2017). Penilaian Gangguan Perilaku Anak Talasemia MAyor dengan Menggunakan The Child Behavior Checklist (CBCL).

Rizkia, S., \& Yusuf, U. (2017). Hubungan antara Religiusitas dengan Psychological Well Being pada Penderita Thalasemia Mayor d i Komunitas " Thaller B272 Bandung .P Psikologi, 395-401.

Saini, A., Chandra, J., Goswami, U., Singh, V., \& Dutta, a K. (2007). Case control study of psychosocial morbidity in beta thalassemia major. The Journal of Pediatrics, 150(5),
$516-520$.

https://doi.org/10.1016/j.jpeds.2007.0 1.025

Sarafino, \& Smith. (2011). Biopsychosocial Interactions. (J. Wiley \& Son, Eds.). New York.

Supratiknya. (1995). Mengenal Perilaku Abnormal. Yogyakarta: Kanisius.

Surilena. (2014). Role of Family Relationships in Teenagers Psychopathology of Thalassemia. Damianus Journal of Medicine, 13(2), 137-147.

Wartini. (2013). Gambaran Kualitas Hidup pada Anak Usia Sekolah yang Menderita Talasemia di Ruang Instalasi Gawat Darurat Anak Rumah Sakit Umum Sumedang.

WHO. (2012). The global burden of disease update. Retrieved from www.who.int/healthinfo/global_burde n\%0A_disease/GBD_report_2004upd ate_\%0Afull.pdf.

Wong D. L., H. M. . (2008). Wong's Nursing care of infants and children. Mosby Company, St Louis Missouri.

Yanitawati, Y., Mardhiyah, A., \& Widianti, E. (2017). Hubungan Perilaku Sakit Dalam Aspek Psikososial Dengan Kualitas Hidup Remaja Thalasemia. Keperawatan, 5(1), 38-47. Retrieved from http://ejournal.bsi.ac.id/ejurnal/index. php/jk/article/view/1572 